\begin{tabular}{|c|l|}
\hline Title & $\begin{array}{l}\text { New Directions: Need for better understanding of plastic waste burning as inferred from high abundance of terephthalic } \\
\text { acid in South A sian aerosols }\end{array}$ \\
\hline Author(s) & Kawamura, K.; Pavuluri, C.M. \\
\hline Citation & $\begin{array}{l}\text { Atmospheric Environment, 44(39), 5320-5321 } \\
\text { https://doi.org/40.1016/.atmosenv.2010.09.016 }\end{array}$ \\
\hline Issue Date & 2010-12 \\
\hline Doc URL & http://hdl.handle.net/2115/48561 \\
\hline Type & article (author version) \\
\hline File Information & AE44.39_5320-5321.pdf \\
\hline
\end{tabular}

Instructions for use 
Submitted to New Directions-AE, May 6, 2010, revised August 31 and September 7, 2010

\section{New Directions: Need for better understanding of plastic waste burning as inferred from high abundance of terephthalic acid in South Asian aerosols}

Terephthalic acid (1,4-benzenedicarboxylic acid; $t-\mathrm{Ph})$ is an important industrial material used for making plastics such as polyester fibre and PET (polyethyleneterephthalate) thermoplastics. In term of public health, $t$-Ph promotes a bladder cancer (Heck and Tyl, 1985). Global consumption of plastics reached 150 millions of tons per year in 2000, with annual growth rate of $5.5 \%$ (Braun, 2004). Global production of polyester fibre alone was 24.5 million tons (65\% of the world chemical fibre market) in 2004, $61 \%$ of which come from Asia, followed by North America and Western Europe (Aizenshtein, 2006). Although plastic materials are increasingly recycled in developed countries, they are dumped as the municipal solid wastes (MSW) in developing countries. The MSW are often burned under open-fire conditions to avoid the spread of mosquitoes that transmit malaria near the dumpsite, emitting plastic decomposition products to the atmosphere.

$t$-Ph has been reported at elevated levels in smoke particles derived from open burning of new plastic bags $\left(907 \mathrm{ng} \mathrm{mg}^{-1}\right)$, roadside litter $\left(5033 \mathrm{ng} \mathrm{mg}^{-1}\right)$ and landfill trash (176 $\mathrm{ng} \mathrm{mg}^{-}$

${ }^{1}$ ) (Simoneit et al., 2005). In addition, secondary formation by atmospheric oxidation reactions may also be significant. However, $t$-Ph has rarely been reported in ambient aerosols that are not derived from open-burning activities such as those listed above (Table 1).

We have analyzed ambient aerosol samples $\left(\mathrm{PM}_{10}\right)$ collected from the megacity Chennai, India $\left(13.04^{\circ} \mathrm{N} 80.17^{\circ} \mathrm{E}\right)$ for molecular distributions of dicarboxylic acids using gas chromatography (GC) and GC/mass spectrometer. The details of the aerosol sampling and analytical procedures are described elsewhere (Pavuluri et al., 2010). Briefly, $\mathrm{PM}_{10}$ samples 
were collected on the rooftop of the Mechanical Sciences Building (18 $\mathrm{m}$ above the ground) at the Indian Institute of Technology Madras campus. The sampling location was not close to a MSW incineration site; rather it is more typical of city background. We detected $t$ - $\mathrm{Ph}$ with very high concentrations ranging from 7.6-168 $\mathrm{ng} \mathrm{m}^{-3}$ (average $45 \mathrm{ng} \mathrm{m}^{-3}$ ) in winter and 24$158 \mathrm{ng} \mathrm{m}^{-3}\left(61 \mathrm{ng} \mathrm{m}^{-3}\right)$ in summer. $t$-Ph was found as the second most abundant dicarboxylic acid in most of the samples, in particular in nighttime samples, following oxalic acid (114-696 $\mathrm{ng} \mathrm{m}^{-3}$ ), which is the most abundant water-soluble organic in particles from many locations around the globe (e.g., Kawamura and Ikushima, 1993). Although phthalic acid (Ph) has been reported as the most abundant aromatic diacid in particles globally, $\mathrm{Ph}$ and isophthalic $(i-\mathrm{Ph})$ acids were rather minor isomers in Chennai aerosols (Pavuluri et al., 2010). $t$-Ph concentrations in Chennai aerosols are 10 times greater than those reported for urban aerosols (TSP) from North America and East Asia as well as marine aerosols (TSP) from the Western Pacific and Southern Ocean (Table 1).

In South Asia, in particular, India, the generation of MSW is very high with a rate of 0.5-0.7 kg capita ${ }^{-1}$ day $^{-1}$ (48 Tg per year; 1997), in which plastics account for $2-8 \% .>90 \%$ of MSW are disposed into open landfills without regulations (Jha et al., 2008), and local residents very often set light to the garbage to avoid the stench from the wastes and the occurrence of mosquito that transmits malaria. Plastics may readily decompose into monomers under open-fire conditions. These monomers can be emitted to the atmosphere and adsorbed onto pre-existing particles. Interestingly, mass concentrations of $t \mathrm{Ph}$ in Chennai aerosols were 55-1620 $\mathrm{ng} \mathrm{mg}^{-1}$ (average $466 \mathrm{ng} \mathrm{mg}^{-1}$ ) in winter and 305-1890 $\mathrm{ng} \mathrm{mg}^{-1}$ (764 ng $\mathrm{mg}^{-1}$ ) in summer. These values are comparable to those reported for smoke particles from plastic bags and wastes as stated above (Simoneit et al., 2005).

These observations indicate that open burning of MSW is the major source of $t$ - $\mathrm{Ph}$ in the aerosols from Chennai rather than emissions from fossil fuel combustion and secondary 
production via the oxidation of its precursor compounds. Thus, the disposal of MSW into landfills followed by firing may deteriorate the local air quality of South India and can lead to climate changes at regional to global scale by emitting significant amount of $t$ - $\mathrm{Ph}$ and other organics, which can further be oxidized to result in more water-soluble organic acids. For example, $t$-Ph may degrade into maleic/fumaric acid followed by oxalic acid under photoFenton oxidation (Thiruvenkatachari et al., 2007). It is of interest to note that the growth rate of municipal waste generation is $61 \%$ from 1996 to 2002 (Jha et al., 2008). There is an urgent need to better understand the effect of solid waste burning on the air quality, public health and potential impact on climate changes. Finally, it is also essential for policy makers to enhance the effective recycling of plastic wastes and to regulate the field burning of MSW disposal in South Asia.

\section{References}

Aggarwal, S.G., Kawamura, K., 2008. Molecular distributions and stable carbon isotopic compositions of dicarboxylic acids and related compounds in aerosols from Sapporo, Japan: Implications for photochemical aging during long-range atmospheric transport. Journal of Geophysical Research 113, D14301, doi:10.1029/2007JD009365.

Aizenshtein, E.M., 2006. World production and consumption of polyster fibres and thread. Fibre Chemistry 38, 264-271.

Braun, D., 2004. Poly(vinyl chloride) on the way from the $19^{\text {th }}$ century to the $21^{\text {st }}$ century. Journal of Polymer Science: Part A: Polymer Chemistry 42, 578-586.

Heck, H.D’A., Tyl, R.W., 1985. The induction of bladder stones by terephthalic acid, dimethyl terephthalate, and melamine (2,4,6-triamino-s-triazine) and its relevance to risk assessment. Regulatory Toxicology and Pharmacology 5, 294-313. 
Jha, A.K., Sharma, C., Singh, N., Ramesh, R., Purvaja, R., Gupta, P.K., 2008. Greenhouse gas emissions from municipal solid waste management in Indian mega-cities: A case study of Chennai landfill sites. Chemosphere 71, 750-758.

Kawamura, K., Ikushima, K., 1993. Seasonal changes in the distribution of dicarboxylic acids in the urban atmosphere. Environmental Science and Technology 27, 2227-2235.

Pavuluri, C.M., Kawamura, K., Swaminathan, T., 2010. Water-soluble organic carbon, dicarboxylic acids, ketoacids and $\alpha$-dicarbonyls in the tropical Indian aerosols. Journal of Geophysical Research 115, D11302, doi:10.1029/2009JD012661.

Simoneit, B.R.T., Kobayashi, M., Mochida, M., Kawamura, K., Lee, M., Lim, H.-J., Turpin, B.J., Komazaki, Y., 2004. Composition and major sources of organic compounds of aerosol particulate matter sampled during the ACE-Asia campaign. Journal of Geophysical Research 109, D19S10, doi:10.1029/2004JD004598.

Simoneit, B.R.T., Medeiros, P.M., Didyk, B.M., 2005. Combustion products of plastics as indicators for refuse burning in the atmosphere. Environmental Science and Technology $39,6961-6970$.

Thiruvenkatachari, R., Kwon, T.O., Jun, J.C., Balaji, S., Matheswaran, M., Moon, I.S., 2007. Application of several advanced oxidation processes for the destruction of terephthalic acid (TPA). Journal of Hazardous Materials 142, 308-314.

Wang, H., Kawamura, K., Yamazaki, K., 2006. Water-soluble dicarboxylic acids, ketoacids and dicarbonyls in the atmospheric aerosols over the Southern Ocean and Western Pacific Ocean. Journal of Atmospheric Chemistry 53, 43-61.

\section{Acknowledgements}


This work is partly supported by funds from JSPS (19204055) and by the Environment Research and Technology Development Fund (B-0903) of the Ministry of the Environment, Japan.

K. Kawamura* and C.M. Pavuluri

Institute of Low Temperature Science, Hokkaido University,

N19 W08, Kita-ku, Sapporo 060 0819, Japan.

*Corresponding author. E-mail: kawamura@lowtem.hokudai.ac.jp 
Table 1. Concentrations of terephthalic acid $(t-\mathrm{Ph})$ in atmospheric particles collected from different locations over the world.

\begin{tabular}{|c|c|c|c|c|}
\hline \multirow[t]{3}{*}{ Sample locale } & \multicolumn{4}{|c|}{ Concentrations } \\
\hline & \multicolumn{2}{|c|}{$\mathrm{ng} \mathrm{m}^{-3}$} & \multicolumn{2}{|c|}{$\mathrm{ng} \mathrm{mg}{ }^{-1}$} \\
\hline & Range & Average & Range & Average \\
\hline \multicolumn{5}{|l|}{ Chennai, India $^{a}$} \\
\hline Jan.-Feb., 2007 & $7.6-168$ & 45 & $55-1620$ & 466 \\
\hline May 2007 & $24.2-158$ & 61.3 & $305-1890$ & 764 \\
\hline \multicolumn{5}{|c|}{ Gosan site (Jeju Island), South Korea ${ }^{b, c}$} \\
\hline April 2001 & & 11 & & 47 \\
\hline \multicolumn{5}{|l|}{ Sapporo, Japan } \\
\hline April $2001^{\mathrm{b}, \mathrm{c}}$ & & 6.3 & & 43 \\
\hline Sept. $2001^{\mathrm{b}, \mathrm{c}}$ & & 0.2 & & 6.5 \\
\hline May-July $2005^{\mathrm{d}, \mathrm{e}}$ & $0.01-5.6$ & 2.6 & $0.12-79$ & 30 \\
\hline \multicolumn{5}{|l|}{ Southern Ocean ${ }^{\mathrm{f}}$} \\
\hline Nov. 1994-Feb. 1995 & $0.01-0.12$ & 0.04 & & 0.48 \\
\hline \multicolumn{5}{|l|}{ Western Pacific Ocean ${ }^{\mathrm{f}}$} \\
\hline Nov. 1994-Feb. 1995 & $<0.01-0.95$ & 0.11 & & 2.8 \\
\hline \multicolumn{5}{|l|}{ Santiago, Chile ${ }^{\mathrm{b}}$} \\
\hline April 1997 & & 3.2 & & $\mathrm{NA}^{\mathrm{g}}$ \\
\hline April 1998 & & 0.5 & & NA \\
\hline April 1999 & & 21 & & NA \\
\hline Nov. 2000 & & 1.1 & & NA \\
\hline \multicolumn{5}{|l|}{ Los Angeles, $\mathrm{CA}^{\mathrm{b}}$} \\
\hline Sept. 1993 & $0.9-17$ & 5.4 & & NA \\
\hline \multicolumn{5}{|l|}{ Corvallis, $\mathrm{OR}^{\mathrm{b}}$} \\
\hline June 1979 & & 0.1 & & NA \\
\hline
\end{tabular}

${ }^{\mathrm{a}}$ This study; ${ }^{\mathrm{b}}$ Simoneit et al., 2005; ${ }^{\mathrm{c}}$ Simoneit et al., 2004; ${ }^{\mathrm{d}}$ Aggarwal and Kawamura, 2008; ${ }^{\mathrm{e}}$ Aggarwal and Kawamura, unpublished data (2005); ${ }^{\mathrm{f}} \mathrm{W}$ ang et al., 2006; ${ }^{\mathrm{g}} \mathrm{NA}$ : Not available. 